\title{
LETTERS
}

\section{Virus-host interactions and the unusual age and sex distribution of human cases of influenza A(H7N9) in China, April 2013}

\author{
D M Skowronski (danuta.skowronski@bccdc.ca) ${ }^{1,2}$, N Z Janjua ${ }^{1,2}$, T L Kwindt ${ }^{1,2}$, G De Serres ${ }^{3,4,5}$ \\ 1. British Columbia Centre for Disease Control, Vancouver, Canada \\ 2. University of British Columbia, Vancouver, Canada \\ 3. Institut National de Santé Publique du Québec (National Institute of Health of Quebec), Québec, Canada \\ 4. Laval University, Quebec, Canada \\ 5. Centre Hospitalier Universitaire de Québec (University Hospital Centre of Quebec), Québec, Canada
}

Citation style for this article:

Skowronski DM, Janjua NZ, Kwindt TL, De Serres G. Virus-host interactions and the unusual age and sex distribution of human cases of influenza A(H7N9) in China, April 2013. Euro Surveill. 2013;18(17):pii=20465. Available online: http://www.eurosurveillance.org/ViewArticle.aspx?Articleld=20465

Article submitted on 24 April 2013 / published on 25 April 2013

To the editor:

Over the past two weeks, Eurosurveillance has published several timely papers related to the emergence of a new influenza $\mathrm{A}\left(\mathrm{H}_{7} \mathrm{~N} 9\right)$ virus affecting humans in China [1-3]. Genetic studies by Kageyama et al. [1] and Jongens et al. [2] assessed evidence in the genome for virus origin, adaptation and virulence, and a paper by Corman et al. [3] described real-time reverse-transcription PCR assays for specific virus diagnosis. While these are important aspects of novel virus characterisation and detection, the accrual of over 100 human cases now also affords opportunity to consider evolving epidemiologic patterns as part of population risk assessment.

Perhaps the most intriguing impression to date from available surveillance findings has been the unexpected age/sex distribution of reported influenza $\mathrm{A}\left(\mathrm{H}_{7} \mathrm{~N}\right.$ 9) cases. The age range spans from 2 to 91 years but two thirds of influenza $\mathrm{A}\left(\mathrm{H}_{7} \mathrm{~N} 9\right)$ cases have been 50 years of age or older and two thirds have been male (Table) $[4,5]$. Illness severity, with a substantial case fatality of $20 \%$, shows a similar age/sex profile (Table) $[4,5]$. Unlike the pattern observed for influenza $A\left(\mathrm{H}_{5} \mathrm{~N}_{1}\right)$, children, both boys and girls and notably the school-aged, are under-represented among influenza $\mathrm{A}\left(\mathrm{H}_{7} \mathrm{~N}\right.$ ) $)$ detections. Among the first 100 adult influenza $A\left(\mathrm{H}_{7} \mathrm{~N} 9\right)$ cases, men and women were equally represented in the youngest age category 20-34 years, but men were 2-3-fold more frequent than women in older age groups (Table). Furthermore, compared with women 20-34 years of age, women 50-64 and 65-79 years were each twice as frequent among influenza $A\left(\mathrm{H}_{7} \mathrm{~N} 9\right)$ detections. Conversely, men $50-64$ and 65-79 years are each 4-5-fold more frequent among influenza $\mathrm{A}\left(\mathrm{H}_{7} \mathrm{~N} 9\right)$ detections than men 20-34 years of age. While being careful not to over-interpret early surveillance data, what hypotheses might be invoked to explain that pattern?

Disease occurrence is the result of the classic interaction triad of agent-host-environment. Environmental

\section{TABLE}

Human cases of influenza A(H7N9) and deaths by age group and sex, China, as of 23 April 2013 (n=109) ${ }^{a}$

\begin{tabular}{|c|c|c|c|c|c|c|c|c|c|c|c|}
\hline & \multicolumn{11}{|c|}{ Age (years) } \\
\hline & $<2$ & $2-4$ & $5-9$ & $10-14$ & $15-19$ & $20-34$ & $35-49$ & $50-64$ & $65-79$ & $\geq 80$ & Unknown \\
\hline Total cases & 0 & 3 & 1 & 0 & 0 & 9 & 16 & 30 & 36 & 12 & 2 \\
\hline Female & 0 & 0 & 1 & 0 & 0 & 4 & 5 & 9 & 9 & 4 & 0 \\
\hline Male & 0 & 2 & 0 & 0 & 0 & 5 & 11 & 21 & 27 & 8 & 0 \\
\hline Unknown & 0 & 1 & 0 & 0 & 0 & 0 & 0 & 0 & 0 & 0 & 2 \\
\hline Deaths & 0 & 0 & 0 & 0 & 0 & 1 & 3 & 6 & 7 & 3 & 1 \\
\hline Female & 0 & 0 & 0 & 0 & 0 & 0 & 1 & 2 & 2 & 0 & 0 \\
\hline Male & 0 & 0 & 0 & 0 & 0 & 1 & 2 & 4 & 5 & 3 & 0 \\
\hline Unknown & 0 & 0 & 0 & 0 & 0 & 0 & 0 & 0 & 0 & 0 & 1 \\
\hline
\end{tabular}

${ }^{a}$ Data sources include the Chinese Center for Disease Control and Prevention and the World Health Organization. 
factors such as differences in poultry exposure due to socio-cultural behaviours and host factors such as healthcare-seeking behaviour or underlying comorbid conditions have been postulated to explain these early influenza $A\left(\mathrm{H}_{7} \mathrm{~N} 9\right)$ surveillance signals $[6,7]$. However, hypotheses should also include the additional perspective of agent (i.e. virus)-host interactions. Immunological profiles by age likely reflect accumulated lifetime opportunities for influenza virus exposure, leaving intricate imprints that may positively or negatively modulate subsequent risk. We have illustrated this immunological complexity at the population level for influenza, showing variation in age-specific cross-reactive antibody levels to previously emerging influenza $A\left(\mathrm{H}_{1} \mathrm{~N}_{1}\right)$ pdmog virus [8] and more recently to the emerging (swine-origin) influenza $A\left(\mathrm{H}_{3} \mathrm{~N}_{2}\right) v$, probably reflecting complex cohort effects based on differential prime/boost exposures to influenza variants by age [9].

That pre-existing immunity can differentially modulate the infection process for novel pathogens may be relevant in understanding the differing age distributions of the emerging influenza $A\left(\mathrm{H}_{5} \mathrm{~N}_{1}\right)$ versus $A\left(\mathrm{H}_{7} \mathrm{~N}_{9}\right)$ viruses [6,7]. Anti-neuraminidase (N1) antibodies induced by cumulative influenza $A\left(\mathrm{H}_{1} \mathrm{~N}_{1}\right)$ lifetime exposures may have a role in mitigating risk and severity of influenza $A\left(\mathrm{H}_{5} \mathrm{~N}_{1}\right)$ infection [10-13] in older individuals accounting for its more youthful profile to date [4-7]. In contrast, for influenza $\mathrm{A}\left(\mathrm{H}_{7} \mathrm{~N} 9\right)$ we may anticipate that anti-N9 antibodies would be less prevalent overall in the population. Other population immunological effects of the 2009 influenza $A\left(\mathrm{H}_{1} \mathrm{~N}_{1}\right)$ pandemic, which affected predominantly young people, such as cross-reactive $\mathrm{T}$-cell responses to generally conserved internal virus proteins [14] or memory B cell responses to shared epitopes within group 1 (i.e. $\mathrm{H}_{1}, \mathrm{H}_{5}$ ) versus group 2 (i.e. $\mathrm{H}_{3}, \mathrm{H}_{7}$ ) subtypes [15] may also need to be considered as factors that influence influenza $A\left(\mathrm{H}_{5} \mathrm{~N}_{1}\right)$ and $\mathrm{A}\left(\mathrm{H}_{7} \mathrm{~N} 9\right)$ age profiles.

At this stage, we should also stay open to the possibility that pre-existing cross-reactive antibodies may actually facilitate the viral infection process, a phenomenon best recognised for dengue through the mechanism of antibody dependent enhancement (ADE) $[16,17]$. ADE is thought to occur when low-levels of weakly heterotypic, cross-reactive but not crossprotective, antibodies generated by past exposure to virus antigen, e.g. through prior infection or immunisation, form bridging complexes to facilitate uptake and replication of related but non-identical variants [16-18]. The possibility of ADE in influenza has long been and remains the subject of intense interest among experts $[19,20]$, for which there may recently be indirect evidence. Early during the 2009 influenza pandemic, we described a potentially important interaction between seasonal and novel emerging influenza virus, notably an approximate doubling of the likelihood of medicallyattended pandemic influenza $A\left(\mathrm{H}_{1} \mathrm{~N}_{1}\right)$ illness among people previously administered seasonal influenza vaccine that contained virus antigenically related but distant from the emerging influenza $A\left(\mathrm{H}_{1} \mathrm{~N}_{1}\right)$ pdmog strain [18]. In a follow-up experiment, vaccinated ferrets showed higher lung virus titres and greater illness severity after influenza $\mathrm{A}\left(\mathrm{H}_{1} \mathrm{~N}_{1}\right)$ pdmog challenge than influenza-naïve animals [21]. In swine, disease exacerbation has also been observed following heterologous challenge [22-24]. ADE was one of the proposed (but unproven) hypotheses to explain the unexpected findings from Canada during the 2009 pandemic [18]. The possible relevance of weakly cross-reactive antibodies in facilitating infection due to other emerging influenza viruses with pandemic potential may therefore warrant further consideration.

In that regard, older Chinese men may not only have a greater likelihood of current poultry/bird exposure, to explain their disproportionate representation among influenza $\mathrm{A}\left(\mathrm{H}_{7} \mathrm{~N} 9\right)$ cases, but also a greater total sum of lifetime avian influenza exposures potentially contributing to cross-reactive $\mathrm{H}_{7}$ antibody. Few serosurveys to assess $\mathrm{H}_{7}$ antibodies in the population of China are available in the English language, and none has yet been sufficiently powered to compare this by age or sex [25-28]. In a serosurvey conducted 20 years ago in central China (Nanchang), 25\% of 100 samples collected from women who raised pigs were found by ELISA to have antibodies to purified $\mathrm{H}_{7}$ antigen [25]. In a more recent serosurvey conducted in 2006-08 in northern China, $5-10 \%$ of ca. 1,000 farmer families and poultry workers aged 5-87 years had detectable but low-level antibodies (titre of at least 1:20 but not exceeding 1:40) to influenza $\left(\mathrm{H}_{7} \mathrm{~N}_{1}\right)$ in a modified haemagglutination inhibition (HI) assay using horse erythrocytes [26]. In 2011 , none of $>1,500$ duck-related workers in Beijing aged $14-71$ years had influenza $\left(\mathrm{H}_{7} \mathrm{~N}_{2}\right)$ or $\left(\mathrm{H}_{5} \mathrm{~N}_{1}\right)$ titres exceeding $1: 40$ by modified $\mathrm{HI}$, although seropositivity to influenza ( $\left.\mathrm{H}_{9} \mathrm{~N}_{2}\right)$ was more prevalent, particularly among adults older than 50 years of age in whom the rate of seropositivity was four-fold higher than among younger participants [28].

Although the detection of antibodies to $\mathrm{H}_{7}$ subtype viruses has proved challenging even among cultureconfirmed cases [29-35], serosurveys to compare crossreactive antibodies and neutralising effects by multiple assays and by age group could be important, not only to inform possible protection, but also to explore patterns of enhanced risk in influenza $\mathrm{A}\left(\mathrm{H}_{7} \mathrm{~N} 9\right)$ affected areas and more broadly elsewhere to inform risk assessment. Certain immunological effects, including ADE as it pertains to influenza, may yet be speculative. At this early stage of trying to understand the unexpected epidemiological patterns of an emerging pathogen, however, it is prudent for the global scientific and public health community to consider all possibilities within the full virus-host-environment paradigm. 


\section{Authors' contributions}

All authors contributed to the writing, review and final approval of this letter.

\section{Conflict of interest}

GDS has received research grants from GlaxoSmithKline (GSK) and Sanofi Pasteur and participated in an ad hoc GSK advisory board meeting for an unrelated issue for which travel expenses were reimbursed. No other authors have competing interests to declare.

\section{References}

1. Kageyama T, Fujisaki S, Takashita E, Xu H, Yamada S, Uchida $\mathrm{Y}$, et al. Genetic analysis of novel avian $\mathrm{A}\left(\mathrm{H}_{7} \mathrm{~N} 9\right)$ influenza viruses isolated from patients in China, February to April 2013. Euro Surveill. 2013;18(15):pii=20453. Available from: http:// www.eurosurveillance.org/ViewArticle.aspx?Articleld $=\mathbf{2 0 4 5 3}$ PMid:23594575.

2. Jonges M, Meijer A, Fouchier RA, Koch G, Li J, Pan JC, et al. Guiding outbreak management by the use of influenza $A(\mathrm{H} 7 \mathrm{Nx})$ virus sequence analysis. Euro Surveill. 2013;18(16):pii=20460. Available from: http://www.eurosurveillance.org/ViewArticle. aspx?Articleld=20460. PMid:23611030.

3. Corman VM, Eickmann M, Landt O, Bleicker T, Brünink S, Eschbach-Bludau M, et al. Specific detection by real-time reverse-transcription PCR assays of a novel avian influenza $\mathrm{A}\left(\mathrm{H}_{7} \mathrm{Ng}\right)$ strain associated with human spillover infections in China. Euro Surveill. 2013;18(16):pii=20461. Available from: http://www.eurosurveillance.org/ViewArticle. aspx?Articleld=20461. PMid:23611031.

4. World Health Organization (WHO). Avian influenza $A\left(\mathrm{H}_{7} \mathrm{~N} 9\right)$ virus. Geneva: WHO. [Accessed 23 Apr 2013]. Available from: http://www.who.int/influenza/human_animal_interface/ influenza_h7ng/en/index.html

5. Li Q, Zhou L, Zhou M, Chen Z, Li F, Wu H, et al Preliminary Report: Epidemiology of the Avian Influenza A ( $\left.\mathrm{H}_{7} \mathrm{~N} 9\right)$ Outbreak in China. N Engl J Med. 24 Apr 2013, DOI: 10.1056/ NEJMoa1304617.

6. Arima Y, Zu R, Murhekar M, Vong S, Shimada T, the World Health Organization Regional Office for the Western Pacific Event Management Team. Human infections with avian influenza $\mathrm{A}\left(\mathrm{H}_{7} \mathrm{~N} 9\right)$ virus in China: preliminary assessments of the age and sex distribution. WPSAR. 2013;4(2). Doi. 10.5365/ wpsar.2013.4.2.005. Available from: http://www.wpro.who.int/ wpsar/volumes/04/2/2013.4.2.005_PE_EMT_Arima.EN.pdf

7. University of Minnesota. Center for Infectious Disease Research \& Policy (CIDRAP). H7N9 mystery: why does age profile tilt older? Minneapolis: CIDRAP. [Accessed 23 Apr 2013]. Available from: http://www.cidrap.umn.edu/cidrap/content/ influenza/h7ng/news/apr1913ageh7.html

8. Skowronski DM, Hottes TS, McElhaney JE, Janjua NZ, Sabaiduc $\mathrm{S}$, Chan T, et al. Immuno-epidemiologic correlates of pandemic H1N1 surveillance observations: higher antibody and lower cell-mediated immune responses with advanced age. J Infect Dis. 2011;203(2):158-67. http://dx.doi.org/10.1093/infdis/ jiq039. PMid:21288814. PMCid:3071066.

9. Skowronski DM, Janjua NZ, De Serres G, Purych D, Gilca V, Scheifele DW, et al. Cross-reactive and vaccine-induced antibody to an emerging swine-origin variant of influenza $A$ virus subtype $\mathrm{H}_{3} \mathrm{~N}_{2}$ (H3N2v). J Infect Dis. 2012; 206(12):185261. http://dx.doi.org/10.1093/infdis/jis500. PMid:22872731.

10. Easterbrook JD, Schwartzman LM, Gao J, Kash JC, Morens DM, Couzens $L$, et al. Protection against a lethal $\mathrm{H}_{5} \mathrm{~N}_{1}$ influenza challenge by intranasal immunization with virus-like particles containin 2009 pandemic $\mathrm{H}_{1} \mathrm{~N}_{1}$ neuraminidase in mice. Virology. 2012;432(1):39-44. http://dx.doi.org/10.1016/j. virol.2012.06.003. PMid:22727831.

11. Chen Z, Kim L Subbarao K, Jin H. The 2009 pandemic $\mathrm{H}_{1} \mathrm{~N}_{1}$ virus induces anti-neuraminidase (NAo antibodies that cross-react with the $\mathrm{NA}_{\text {of }} \mathrm{H}_{5} \mathrm{~N}_{1}$ viruses in ferrets. Vaccine. 2012;30(15):2516-22. http://dx.doi.org/10.1016/j. vaccine.2012.01.090. PMid:22330124.

12. Perrone LA, Ahmad A, Veguilla V, Lu X, Smith G, Katz JM, et al. Intranasal vaccination with 1918 influenza virus-like particles protects mice and ferrets from lethal 1918 and $\mathrm{H}_{5} \mathrm{~N}_{1}$ influenza virus challenge. J Virol. 2009;83(11):5726-34. http://dx.doi. org/10.1128/JVI.00207-09. PMid:19321609. PMCid:2681940.

13. Rockman S, Brown LE, Barr IG, Gilbertson B, Lowther S, Kachurin A, et al. Neuraminidase-inhibiting antibody is a correlate of cross-protection against lethal $\mathrm{H}_{5} \mathrm{~N}_{1}$ influenza virus in ferrets immunized with seasonal influenza vaccine. J Virol. 2013;87(6):3053-61. http://dx.doi.org/10.1128/JVI.0243412. PMid:23283953.

14. Hillaire MLB, Vogelzang-van Trierum SE, Kreijtz JHCM, de Mutsert G, Fouchier RAM, Osterhaus ADME, et al. Human T-cells directed to seasonal influenza A virus cross-react with 2009 pandemic influenza $A\left(\mathrm{H}_{1} \mathrm{~N}_{1}\right)$ and swine-origin triplereassortant $\mathrm{H}_{3} \mathrm{~N}_{2}$ influenza viruses. J Gen Virol. 2013;94 $\mathrm{Pt}$ 3):583-92. http://dx.doi.org/10.1099/vir.0.048652-0. PMid:23152369.

15. Mahallawi WH, Kasbekar AV, McCormick MS, Hoschler K, Temperton N, Leong SC, et al. $2009 \mathrm{H}_{1} \mathrm{~N}_{1}$ infection primes for immunological memory in human nasal-associated lymphoid tissue that offers cross-reactive immunity to $\mathrm{H}_{1} \mathrm{~N}_{1}$ and avian $\mathrm{H}_{5} \mathrm{~N}_{1}$ viruses. J Virol. 2013 Mar 6. [Epub ahead of print]. 
16. Stephenson JR. Understanding dengue pathogenesis: implications for vaccine design. Bull World Health Organ. 2005;83(4):308-14. PMid:15868023. PMCid:2626214.

17. Midgley CM, Bajwa-Joseph M, Vasanawathana S, Limpitikul W, Wills B, Flanagan A, et al. An in-depth analysis of original antigenic sin in dengue virus infection. J Virol. 2011;85(1):410 21. http://dx.doi.org/10.1128/JVI.01826-10. PMid:20980526. PMCid:3014204.

18. Skowronski DM, De Serres G, Crowcroft NS, Janjua NZ, Boulianne N, Hottes TS, et al. Association between the 2008-09 seasonal influenza vaccine and pandemic $\mathrm{H}_{1} \mathrm{~N}_{1}$ illness during spring-summer 2009: Four observational studies from Canada. PLoS Med. 2010;7(4):e1000258. http:// dx.doi.org/10.1371/journal.pmed.1000258. PMid:20386731. PMCid:2850386.

19. Gotoff R, Tamura M, Janus J, Thompson J, Wright P, Ennis FA. Primary influenza A virus infection induces cross-reactive antibodies that enhance uptake of virus into Fc receptorbearing cells. J Infect Dis. 1994;169(1):200-3. http://dx.doi. org/10.1093/infdis/169.1.200. PMid:8277183.

20. Dutry I, Yen H, Lee H, Peiris M, Jaume M. Antibody-dependent enhancement (ADE) of infection and its possible role in the pathogenesis of influenza. BMC Proc. 2011;5(Suppl 1):P62.

21. Skowronski DM, Hamelin ME, De Serres G, Janjua NZ, Li G, Bouhy $X$, et al. Prior receipt of 2008-09 trivalent inactivated influenza vaccine increases pandemic $\mathrm{H}_{1} \mathrm{~N}_{1}$ severity in ferrets: randomized double-blind placebo-controlled experiment. Abstract and poster to 52nd ICAAC (Interscience Conference on Antimicrobial Agents and Chemotherapy). San Francisco, CA, USA. 9-12 Sep 2012.

22. Vincent $A L$, Lager $K M$, Janke $B H$, Gramer $M R$, Richt JA. Failure of protection and enhanced pneumonia with a US $\mathrm{H}_{1} \mathrm{~N}_{2}$ swine influenza virus in pigs vaccinated with an inactivated classical swine $\mathrm{H}_{1} \mathrm{~N}_{1}$ vaccine. Vet Microbiol. 2008;126(4):310-23. http:// dx.doi.org/10.1016/j.vetmic.2007.07.011. PMid:17719188.

23. Gauger $P C$, Vincent $A L$, Loving $C L$, Lager $K M$, Janke $B H$, Kehrli ME Jr., et al. Enhanced pneumonia and disease in pigs vaccinated with an inactivated human-like ( $\delta$-cluster) $\mathrm{H}_{1} \mathrm{~N}_{2}$ vaccine and challenged with pandemic $2009 \mathrm{H}_{1} \mathrm{~N}_{1}$ influenza virus. Vaccine. 2011;29(15):2712-9. http://dx.doi.org/10.1016/j. vaccine.2011.01.082. PMid:21310191.

24. Gauger PC, Vincent AL, Loving CL, Henningson JN, Lager KM, Janke $\mathrm{BH}$, et al. Kinetics of lung lesion development and pro-inflammatory cytokine response in pigs with vaccineassociated enhanced respiratory disease induced by challenge with pandemic (2009) A/H1N1 influenza virus. Vet Pathol.2012; 49(6):900-12. http://dx.doi.org/10.1177/0300985812439724. PMid:22461226.

25. Zhou N, He S, Zhang T, Zou W, Shu L, Sharp GB, et al. Influenza infection in humans and pigs in southeastern China. Arch Virol. 1996;141(3-4):649-61. http://dx.doi.org/10.1007/BF01718323. PMid:8645101.

26. Jia N, de Vlas SJ, Liu Y-X, Zhang J-S, Zhan L, Dang R-L, et al. Serological reports of human infections of $\mathrm{H}_{7}$ and $\mathrm{H} 9$ avian influenza viruses in northern China. J Clin Virol. 2009;44(3):225-29. http://dx.doi.org/10.1016/j. jcv.2008.12.014. PMid:19186101.

27. Liu Y, Lu EJ, Wang YL, Di B, Li TG, Zhou Y, et al. Avian influenza virus infection in people occupied in poultry fields in Guangzhou city. Zhonghua Liu Xing Bing Xue Za Zhi. 2009;30(11):1111-3. Chinese. PMid:20193575.

28. Yang P, Ma C, Shi W, Cui S, Lu G, Peng X, et al. A serological survey of antibodies to $\mathrm{H}_{5}, \mathrm{H}_{7}$ and $\mathrm{H}_{9}$ avian influenza viruses amongst the duck-related workers in Beijing, China. PLoS One. 2012;7(11):e50770. http://dx.doi.org/10.1371/journal. pone.0050770. PMid:23226380. PMCid:3511333.

29. Bosman A, Mulder YM, de Leeuw JRJ, Meijer A, Du Ry van Beest Holle M, Kamst RA, et al. Executive summary avian flu epidemic 2003: public health consequences. Bilthoven: RIVM 2004. Rep 630940004/2004. Available from: www.rivm.nl/ bibliotheek/rapporten/630940004.pdf

30. Fouchier RA, Schneeberger PM, Rozendaal FW, Broekman JM, Kemink SA, Munster V, et al. Avian influenza A virus ( $\mathrm{H} 7 \mathrm{~N} 7$ ) associated with human conjunctivitis and a fatal case of acute respiratory distress syndrome. Proc Natl Acad Sci U S A. 2004;101(5):1356-61. http://dx.doi.org/10.1073/ pnas.0308352100. PMid:14745020. PMCid:337057.

31. Stephenson I, Wood JM, Nicholson KG, Zambon MC. Sialic acid receptor specificity on erythrocytes affects detection of antibody to avian influenza hemagglutinin. J Med Virol. 2003;70(3):391-8. http://dx.doi.org/10.1002/jmv.10408. PMid:12767002.

32. Du Ry van Beest Holle $M$, Meijer A, Koopmans $M$, de Jager CM. Human-to-human transmission of avian influenza $A / \mathrm{H}_{7} \mathrm{~N}_{7}$, The Netherlands, 2003. Euro Surveill. 2005;10(12): $\mathrm{pii}=584$.
Available from: http://www.eurosurveillance.org/ViewArticle. aspx?Articleld=584. PMid:16371696.

33. Meijer A, Bosman A, van de Kamp EE, Wilbrink B, Du Ry van Beest Holle M, Koopmans M. Measurement of antibodies to avian influenza virus $\mathrm{A}\left(\mathrm{H}_{7} \mathrm{~N} 7\right)$ in humans by hemagglutination inhibition test. J Virol Methods. 2006;132(1-2):113-20. http:// dx.doi.org/10.1016/j.jviromet.2005.10.001. PMid:16271401.

34. Skowronski DM, Li Y, Tweed SA, Tam TWS, Petric M, David $S T$, et al. Protective measures and human antibody response during an avian influenza $\mathrm{H}_{7} \mathrm{~N}_{3}$ outbreak in poultry in British Columbia, Canada. CMAJ. 2007;176(1):47-53. http://dx.doi. org/10.1503/cmaj.060204. PMid:17200390. PMCid:1764568.

35. Tweed SA, Skowronski DM, David ST, Larder A, Petric M, Lees W, et al. Human illness from avian influenza $\mathrm{H}_{7} \mathrm{~N}_{3}$, British Columbia. Emerg Infect Dis. 2004;10(12):2196-9. http://dx.doi. org/10.3201/eid1012.040961. PMid:15663860. PMCid:3323407. 